\title{
THE BALTIC ENVIRONMENTAL INFORMATION DISSEMINATION SYSTEM - USING ENVIRONMENTAL INFORMATICS AS A TOOL FOR SUSTAINABLE DEVELOPMENT IN THE BALTIC SEA REGION
}

\author{
Walter Leal Filho \\ Technical University Hamburg-Harburg Technology (TuTech) - Schellerdamm 4 - D-21079 Hamburg - Germany \\ Corresponding author<leal@tutech.de>
}

\begin{abstract}
The on-going economic development of EU-countries as well of the countries in the C\&E European region has been leading to a significant use of a great deal of natural resources as well as to noticeable environmental problems. The lack of a wide-spread environmental awareness from the side of those acting in various sectors (industry, public administration, users) sometimes inhibit the implementation of legislation already available as well as the introduction of new technologies deriving, from example, from marine research. An example of this state of affairs is seen in respect of the implementation of the recommendations deriving from Baltic 21 and VASAB 2010, which illustrate the advantages from a cross-sectorial, open mechanism for the dissemination of environmental information in the region. There are various organisations today which act as suppliers of environmental information in the Baltic Sea Region. However, few, if any, are providers concerned with the various ways in which information on matters related to sustainable development is being used by various groups and audiences. This state of affairs makes it necessary to enhance the current mechanisms and approaches in place, so as to enable the wide-range of environmental information available today from areas such as marine research, to be more widely used. It is equally important that the didactic or educational potential of such information be exploited, so as to not only inform, but also to educate various groups and the general public on matters concerned with the environment in European closed seas and give information to planners and politicians to prepare decisions. In order to address such needs, the project "Baltic Environmental Information Dissemination System (BEIDS)" was set in motion. BEIDS has been taking advantage of the most modern information technologies and has been acting as a focal point for the circulation of intelligent information on aspects of the marine environment, but also emphasising related areas such as transport and sustainable development issues, among a sample of six BSR countries: Denmark, Finland, Germany, Sweden (EU) and Lithuania and Poland (non-EU), contributing to networking and know-how exchange, complementing efforts towards transregional cooperation in sustainable spatial planning on the basis of Baltic 21. The results reached to date include: increased awareness of matters related to sustainable development in the six participant countries; enhanced communication exchange and networking among the sample nations; improved information flow and increased participation in events, activities and programmes across the Baltic Sea Region. BEIDS is a prime example of the feasibility of using environmental informatics as a tool for sustainable development. Key words: Europe, Baltic Sea, environment, communication, internet
\end{abstract}

\section{O SISTEMA BÁLTICO DE DISSEMINAÇÃO DE INFORMAÇÃO AMBIENTAL - O USO DE INFORMÁTICA AMBIENTAL COMO UMA FERRAMENTA PARA O DESENVOLVIMENTO SUSTENTÁVEL NA REGIÃO DO MAR BÁLTICO}

RESUMO: O atual desenvolvimento econômico da Comunidade Européia, bem como a região C\&E Européia, tem levado a um uso intenso de muitos recursos naturais e a um reconhecimento de problemas ambientais. A falta de uma ampla consciência por parte daqueles que atuam em vários setores (indústria, administração pública, usuários) as vezes inibe a implementação de legislação já disponível, como também a implementação de novas tecnologias provenientes, por exemplo, da pesquisa marinha. Um exemplo deste estado de fato ser visto em relação a implementação das recomendações saídas do "Baltic 21" e VASAB 2010, que ilustram as vantagens de um mecanismo aberto, trans-setorial para a disseminação de informação ambiental na região. Hoje estão presentes várias organizações que atuam como fornecedoras de informação ambiental na região do Mar Báltico. Entretanto, apenas algumas, ou nenhuma são provedoras conscientes com os vários modos em que a informação a respeito de desenvolvimento sustentável está sendo utilizada pelos vários grupos e audiências. O estado atual da questão torna necessário impulsionar os mecanismos existentes em seu lugar, de tal forma a propiciar que o amplo espectro de informação ambiental disponível hoje nas áreas tais como a pesquisa marinha, sejam utilizadas com mais intensidade. É igualmente importante que o potencial didático 
e educacional de tais informações sejam exploradas, de tal forma a não só informar, mas também educar vários grupos e o público em geral, sobre matérias relacionadas com o ambiente em mares europeus fechados, e dar informações para planejadores e políticos para preparação de decisões. Para levar em conta estas necessidades, o projeto "Sistema Báltico de Disseminação de Informação Báltica (BEIDS)" foi colocado em movimento. BEIDS tem se aproveitado das tecnologias mais modernas de informação e atua com um ponto focal para a circulação de informação inteligente sobre aspectos do ambiente marinho, e também dando ênfase à áreas correlatas como as do transporte e desenvolvimento sustentável, entre uma amostra de seis países bálticos: Dinamarca, Finlândia, Alemanha, Suécia (EU), Lituânia e Polônia (não-EU), contribuindo para uma troca de "know-how" em rede, complementando esforços para uma cooperação transregional no planejamento espacial sustentável, dentro das bases do "Baltic 21". Os resultados obtidos até o momento incluem: uma consciência ampliada sobre matérias relacionadas ao desenvolvimento sustentável dentro dos seis países participantes; troca de informações ampliadas e estabelecimento de redes entre as nações; fluxo melhorado de informações e um aumento na participação de eventos, atividades e programas que envolvem a região do Mar Báltico. BEIDS é um excelente exemplo de viabilidade do uso de informática ambiental como uma ferramenta para o desenvolvimento sustentável.

Palavras-chave: Europa, Mar Báltico, meio ambiente, comunicação, internet

\section{INTRODUCTION}

\section{Marine research in the Baltic Sea Region}

The Baltic Sea is one of the major brackish water basins of the world. The Baltic Sea Region constitutes about $15 \%$ of the European land area and $10 \%$ of its total population. The Baltic coast is 7,200 kilometres long. About 90 million people are settled in the entire Baltic drainage area. Approximately 16 million people inhabit the Baltic coastal areas of Denmark, Estonia, Finland, Germany, Latvia, Lithuania, Poland, Russia and Sweden (Figure 1).

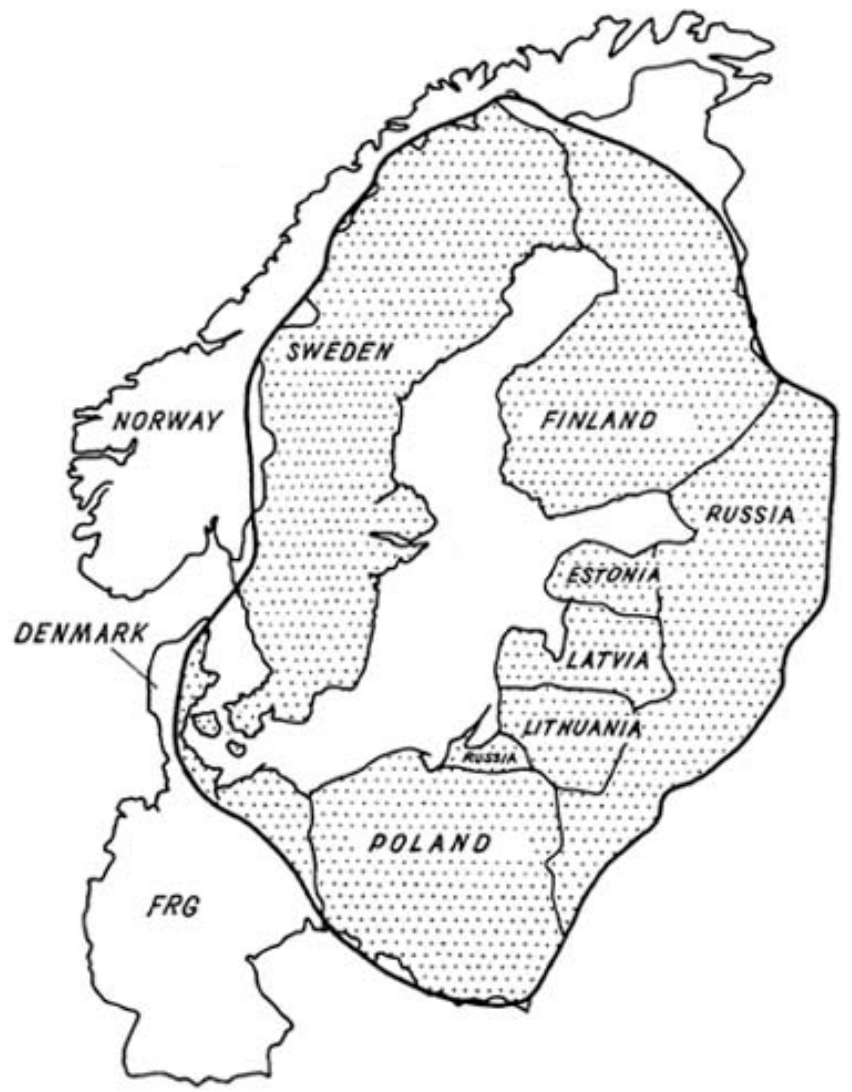

Figure 1- The Baltic Sea Region.
The history of this unique aquatic system, which is a product of the last glacial period covers about the same time scale as the development of the human beings since the stone age. The Baltic Sea has always been of great importance for the people living around it, providing a common bond as well as routes of navigation between the current nine bordering countries. Its fisheries represent a valuable part of each country's livelihood and its waters are also a recreational resource of increasing value (Kindler \& Lintner, 1993, Joenniemi, 1993).

Otherwise, for the almost 85 million people living in the drainage area which is shared by 15 countries with mostly high-developed industry and agriculture, the Baltic Sea is exploited also as a huge natural wastewater treatment plant which is expected to cope with discharges of different origin and composition. The Baltic Sea ecosystem is able to assimilate some anthropogenic inputs, but recycled and more persistent compounds may, however, build up in the system with impacts on its functioning and stability.

The very specific hydrographic, chemical and physical conditions, and the geological history of the Baltic Sea explain why it hosts quite unusual aquatic biota. A number of species of marine and freshwater organisms live side by side. Although the overall number of species found in the Baltic sea is relatively small, some occur in abundance. Most are necessary to keep the ecosystem in balance. This is also true for sea birds and marine mammals who are endangered, inter alia, by virtue of their high level in the food web, and this influences their uptake of harmful lipophilic organohalogens through bioaccumulation.

The multitude and beauty of coastal landscapes around the Baltic Sea area represents a heritage for the present society. It deserves protection against the anthropogenic pressure caused by activities in the drainage area, at the shoreline and on sea.

There is today a wide range of projects and research studies being performed in the Baltic Sea, in which environmental informatics has been used. For example, the BALTIC web study, where all info on 
hydrochemical conditions in the Baltic Sea are recorded and up-kept. An extensive detailed presentation of nutrient and oxygen distributions, for example, with monthly resolution based on an extensive database obtained from almost all institutes involved in Baltic Sea monitoring and research, is found in BALTIC 96 and 97 and 98 (http://data.ecology.su.se/baltic96/). Moreover, the GRID-Arendall Centre in Norway (http://www.grida.no), provides an initial setting from which information on other marine research works may be obtained.

Public opinion about the state of the Baltic Sea is strongly influenced by the media which, from time to time, pick up certain dramatic events and episodes, frequently judging them in a negative ("...The Baltic Sea is dying...") and only occasionally positive ("...Most of the Baltic Sea problems are solved...") manner. Without providing at the same time necessary background information about the possible causes and the scale of those events, and how they fit into more general trends and tendencies, a misleading picture may be generated which tends to persist in the minds of the general public.

The above state of affairs, with considerations deriving from experiences gathered from the BALTIC web study and other regional projects, outlines the need for environmental information systems, which may provide timely and useful information on aspects of marine research per se and on broad environmental issues in particular. The subsequent parts of this paper will deal with the use of marine research to support policy-making and will introduce a system designed to rationalise the use of environmental information.

Using knowledge of environmental informatics on marine research towards improvements in decisions support systems and towards sustainable development: some practical examples 'Similar to other sets of data, marine environmental data specific to the Baltic Sea on matters such as nutrients (Gren et al. 1997), freshwater flows (Jansson et al. 1999) or on the impacts of economic activities such as agriculture (Jansson, 1997) lie dispersed across the region in collections maintained by many different laboratories, government agencies, local/regional authorities, university departments, institutes, data centres and private companies. These range from professionally managed holdings and computer databases, to ad-hoc files and collections of hard-copy material and samples such as sediment cores and biological specimens. Individually, these data have a rather limited application. Collectively however, these data represent an immense resource for studying the environment not only of the Baltic sea and seas around Europe, but also further afield into the deep ocean and beyond.

A first example of a practical initiative aimed at using knowledge of informatics combined with marine research to policy-making comes from the "European Directory of Marine Environmental Data" (EDMED), available at http://www.nbi.ac.uk/bodc/edmed.html. It is the aim of EDMED to provide a comprehensive reference to the marine environmental data held within Europe so as to provide marine scientists, engineers and policy makers with the means of identifying potentially useful data sets.

Data sets are catalogued in EDMED irrespective of their format (e.g. digital databases or files, analogue records, paper charts, hard-copy tabulations, geological and biological samples, etc.) and include data collected from the last century through to the present. They cover a wide range of disciplines including marine meteorology; physical, chemical and biological oceanography; marine biology and fisheries; environmental quality monitoring; marine geology and geophysics, etc.

The majority of data sets within EDMED (EDMED, 1999) relate to the seas around Europe but entries will found for most of the seas and oceans of the world. It should be noted that, although a few data sets include remote-sensing data, the Directory does not provide full coverage of satellite sensed data sets as these tend to be documented internationally by the remote-sensing community.

Although EDMED is targeted primarily at data sets that can be made accessible to other users, encouragement has also been given to holders of working data sets, or data of a confidential or restricted availability, to make their data known through the Directory. As of September 1996, EDMED contains descriptions of 2180 data sets from 453 centres in eleven countries (EDMED, 1999).

In addition, the earlier mentioned project Baltic Sea Marine Environment or "Baltic Sea Web“ is a geographical user interface for network-based Baltic Marine Environment Information System (Baltic Sea Web, 1999). The initial aim of the project was to launch a Baltic Marine Environment Information System which allows users to search information using a geographical user interface with connection to text retrieval tools and to retrieve bibliographic references as well as electronic original documents over the Internet. It promotes, facilitates and improves co-operation, resource sharing and networking between libraries in Baltic Sea countries. The information system developed is an extension of an existing bibliographic database, which is accessible via traditional online information retrieval systems as well by common WWW search form. Because a sizeable number of the bibliographic references in the database have an identifiable geographical content, they have previously been relatively poorly accessible to professional and end users. For this reason a new geographical user interface was developed.

The project has yielded a demonstrator (i.e. an Internet based service), which greatly improves the accessibility and usefulness of the existing database on Baltic marine environment issues. Two versions of the prototype demonstrator are available for viewing. Their usefulness can later be improved by adding more 
content, including more original documents. They are likely to serve as a generic model for future developments in the area of enhanced information retrievability (Baltic Sea Web, 1999).

A comprehensive set of data on different aspects of the Baltic Sea is stored at the UNEP GRID Centre in Arendal, Norway (www.grida.no), which also hosts the BALLERINA database (www.baltic-region.net/). Although this service is temporarily suspended, the database has in the past been widely used as a tool for information gathering and exchange among government and nongovernment agencies from across the region.

Moreover, the project BALTEX (Baltic Sea Experiment) details on which being available at http:// w3.gkss.de/baltex/baltex_frame_builder.html, has proven instrumental in attempts to explore and model the various mechanisms determining the space and time variability of energy and water budgets of the BALTEX area and its interactions with surrounding regions. The idea is to relate these mechanisms to the large-scale circulation systems in the atmosphere and oceans over the globe, to develop transportable methodologies in order to contribute to basic needs of climate-, climate impact-, and environmental- research in other regions of the world (BALTEX, 1999).

BALTEX comprises both meteorological and hydrological research. Additionally, it has a strong oceanographic research component, at present a unique feature among the GEWEX regional-scale projects. BALTEX is designed as a cage experiment to assess the total heat and water flux divergence of the BALTEX area. The basic BALTEX programme elements include numerical modelling, data assimilation, experimental and numerical process studies, re-analysis of existing data sets, and application of remote sensing. Remote sensing data from satellites and radar, for example, provide essential information for areal survey of a variety of atmospheric and surface properties and processes in the BALTEX area.

As could be seen from the above examples, the knowledge from environmental informatics combined with knowledge obtained from marine research may be a potential tool for policies. For example, the framework of the Convention on the Protection of the Marine Environment of the Baltic Sea Area (Helsinki, 1974, revised 1992), was heavily based on the state-of-the-art scientific information provided by marine studies. Indeed, the state of the Baltic Sea is regularly assessed in about 5-year intervals and policy-making is often influenced by the results of such studies, in which hundreds of experts from a multitude of disciplines participate. The outcome is a basically scientific background document covering most of the topics related to the state of the Baltic Sea. The respective situation, trends and tendencies are highlighted.

The above outlined multidisciplinary approach attempts to secure a balanced view on different problems. As typical for any science, a compilation of today's results does not provide 'final answers' even when the Baltic Sea belongs to one of the longest and most intensively studied sea areas of the world. The assessments are understood to be a time limited consensus which has been reached between scientists participating in long-term studies.

Since the signing of the Helsinki Convention in 1974, HELCOM has become the main forum for handling environmental issues in the Baltic Sea Area. During the first 15 years, work was focused on environmental problems. The environmental efforts, however, could not stop the ongoing loss of habitats and biotopes, and hence the permanent threat to the biodiversity in many parts of the Baltic Sea Area. However, new thinking strongly suggested that other measures were necessary in order to protect biodiversity and ecologically important areas and processes, and thus a revision of the Convention was called for.

As a result of recommendations from the Ministerial Meeting at Ronneby, Sweden, in September 1990, and from the First International Seminar on Nature Conservation and Biodiversity in the Baltic Region at Runö, Sweden, in May 1991, a new article was drafted for the revised Helsinki Convention of April 1992. Article 15 of this new Convention states:

"The Contracting Parties shall individually and jointly take all appropriate measures with respect to the Baltic Sea Area and its coastal ecosystems influenced by the Baltic Sea to conserve natural habitats and biological diversity and to protect ecological processes. Such measures shall also be taken in order to ensure the sustainable use of natural resources within the Baltic Sea Area. To this end the Contracting Parties shall aim at adopting subsequent instruments containing appropriate guidelines and criteria".

Hence, not only the Baltic Sea itself is included within the frame of HELCOM, but also terrestrial biotopes of the Baltic Sea coasts, as far as nature conservation aspects are concerned. The protection of habitats, species and ecological processes, both in marine and coastal areas, are important in the improvement of the environmental situation of the Baltic Sea Area in future. With "Article 15 - Nature Conservation and Biodiversity", environmental work in the Baltic Sea was elevated to a different level and has since included nature conservation as an important tool.

\section{The Baltic Environmental Information Dissemination System: a case study}

Initiated in October 1999 as an Interreg IIC project led by the Department of Environment of the Free and Hanseatic City of Hamburg, the purpose of BEIDS, the Baltic Environmental Information Dissemination System (www.beids.de), is to bring to life an environmental information system for the BSR which serves the purpose of promoting concerted spatial planning, cross-sectorial networking and improved social and economic cohesion in the region. 
An information system (IS), no matter on the topic it is related to, is based on the collection of information about a theme, which can be accessed whenever the information is required. The role of an IS is to make sure that the relevant information is available in the right place at the right time (Leal Filho, 2000). To this purpose, the information may be saved in a specific format and:

be called upon a selected via a pre-chosen "call system“ such as the visit to a web site, from where the information required by users may be downloaded (active or subjective usage);

be transmitted to a selected group of users, on the basis of their interest on a theme (passive or objective usage).

In other words:

\section{Active usage}

User $\Rightarrow \Rightarrow \Rightarrow \Rightarrow$ Call Web Site $\Rightarrow \Rightarrow \Rightarrow \Rightarrow$ Pick-up information or $\Rightarrow \Rightarrow \Rightarrow \Rightarrow \Rightarrow$ Desingage Surf

\section{Passive usage}

Central Office $\Rightarrow \Rightarrow \Rightarrow \Rightarrow \Rightarrow$ Call User $\Rightarrow \Rightarrow \Leftrightarrow \Rightarrow \Rightarrow$ Supply information $\Rightarrow \Leftrightarrow \Rightarrow \Rightarrow \Rightarrow$ Desingage

The advantage of active usage is that users may be able to choose from a wide range of data, the ones they are interested at. The disadvantage of this approach is that it is often time-consuming and the range of topics may lead -except to professional users- to some initial confusion since there is much on offer. On the other hand, the advantage of the passive usage relies on the fact that the information is targeted to the theme on which a certain group wants to obtain information on, thus saving time and resources. A disadvantage of the passive usage is that the data is limited to the set the user has shown an interest on and nothing else.

Certain groups such as research organisations and NGOs may also wish to work via a IS which favours active usage, while other such as the scientific and industry sector may prefer objective usage since extra use of time and extra efforts are spared. Both have their pros and cons. A truly flexible IS, here also taking into account the environment as a context, is able to provide its users with both options. The Baltic Environmental Information Dissemination System, due the plurality of users, caters for both passive and active usage.

Depending on the type of information an IS is expected to disseminate, use can be made of databanks management systems (DMS) or Information Retrieval Systems (IRS). For some time now, a link between DMS and IRS has been advocated, converging towards a Databank Management and Retrieval System (DMRS). The BEIDS project favour this approach, so as to meet the varied information needs of its beneficiaries in the field of environment. This has led to improved access, structured use and flexibility in operation, since users can access the latest information and, via the DMRS, refers to past information as well. Last but not least, the use of DMRS offers a historical view of the development of the topics covered in the project, over the course of its evolution.

An innovative approach of BEIDS is that its focus on DMRS is decentralised, i.e. BEIDS routes users interested on information already kept at databases (e.g. BALLERINA, GRID-Arendall) to them, focusing its work on information retrieval. The advantage of such an approach are twofold:

a) it links up BEIDS with already existing operational databases, through synergy, minimising the duplication of efforts and

b) it enables it to manage information on various formats, so as to enable the smooth dissemination (e.g. text rich files, word processing programmes, e-mail, etc).

Documents, communications, reports, policy texts, books, pictures, measurements and satelliteoriginated information may be disseminated as and when needed, in support of marine research and broad environmental conservation in Baltic Sea countries. It may be once again pointed out that, the information management system implemented as part of BEIDS focuses on three key themes: energy, transport and sustainability (in the context of which marine research is included), which enables it to sharply address the information needs of its beneficiaries.

As any IS, BEIDS needs to be able to be assessed and evidences of its usefulness need to be provided to both, the agencies funding it and to the general public. To this purpose, a number of impact indicators are being used. These are:

Qualitative indicators:usability and acceptance of BEIDS's products and services; variety of groups reached within each sector; profile of users of BEIDS; degree of participation from the government/ administration and industry sector; levels of interest on BEIDS from the educational and NGO sector.

Quantitative indicators: number of people reached in each category; number of regular users of the BEIDS Web-site; number of messages, information on projects, briefings circulated; projects and commercial initiatives catalysed; number of training and briefing sessions organised.

Over and above the listed areas, the impact of BEIDS is also felt in the areas of transport and energy themselves. In the transport area, BEIDS has been paying a special emphasis to developments on road building and access (especially in Sweden and Denmark where this sector is developing rapidly in respect to connections with northern Germany), and on harbours (Hamburg and Gdansk are two of northern Europe's largest harbours and vital to the economies of these 
cities). The system has recently been involved with the promotion of information on the newly-opened Öresund bridge, linking the cities of Malmö (Sweden) and Copenhagen (in Denmark).

In respect of energy, the rapidly changing developments in energy industries and markets and the environmental aspects of energy exporting projects (wind energy, natural gas and refining in particular) warrant the attention BEIDS has been paying to them. The developments in the field of renewable energy over the past year in particular have been remarkable and BEIDS has been playing an important role in catalysing the dissemination of the available information.

BEIDS is expected not only to simply be one more information tool, but an integrated information system where environmental information, a valuable good in today's world, is put to full use.

In order to fulfil its aims, BEIDS has an ample spectrum of beneficiaries, upon which its impact will be felt. These beneficiaries may be included under five main categories: The government sector, for the system shall reach decision-makers who shall be better informed in relation to environmental affairs and support for examples, the VASAB 2010 process and Baltic 21; The public administration sector at the national, regional and local level who prepare and implement government decisions and the following of policies; The industry sector including small and medium-enterprises (SMEs) and large concerns; The educational sector, from high schools to universities, including researchers and teacher trainers; The voluntary sector, via non-governmental organisations, who are always in need of information for their projects.

The project cooperates with a wide range of projects such as BERNET, STRING and BALTICOM, by liaising and by making its database available for those projects. In addition, links with relevant EU and non-EU funded projects are analysed and whenever appropriate pursued, so as to minimise the risks of overlapping and duplication also in relation to the dissemination of information. This is a pilot project whose holistic and combined approach to transport-energy and sustainable development, important elements of spatial planning, is no doubt be of interest to other projects and may to a certain extent support other attempts to promote sustainable development in BSR countries. The project is not related to other national projects, but there is already an interested expressed in some countries, in the technological approaches in relation to telecommunication for environmental protection, which might be of interest and indeed eventually be used by some countries in the region. It is also an attempt to meet the challenges of the Baltic 21 and the VASAB 2010 action plan.

The BEIDS project complements the abovementioned initiatives in the sense that it is the first project to focus on the use of information technologies to disseminate environmental information in the fields of energy, transport and sustainable development to a selected audience, on a participatory basis. It thus complements HELCOM's FPAEE (a network of government and non-government agencies working on environmental education which meets twice/thrice a year); BUP (a network of universities teaching environment courses of regional interest); BALLERINA (an environment database of regional scope and entailing links to organisations individual countries); and UNEPGRID which runs specific projects, especially on remote sensing and chemical analyses. By way of such partnerships, risks of duplications are minimised, also in relation to the dissemination of results since concerted action is envisaged.

The results reached to date include: increased awareness of matters related to sustainable development in the six participant countries; enhanced communication exchange and networking among the samples nations; improved information flow and increased participation in events, activities and programmes across the Baltic Sea Region. BEIDS is a prime example of the feasibility of using information on marine research as a tool for sustainable development.

\section{The future of environmental information and dissemination systems}

The potential applications of environmental information systems contexts such as marine research as a whole and to specific schemes such "Third Periodic Assessment of the State of the Marine Environment of the Baltic Sea" in particular, is threefold. First, they document the existence of marine research initiatives and refer to the results they gather, thus ensuring these different experiences are not lost. Second, they disseminate the information among groups which would otherwise not know about them. Third, they catalyse cooperation and networking between groups such as scientists and civil servants, or scientists and policymakers (members of parliament, ministers etc), also leading to links which may reflect in the ways policies are made.

Information systems such as BEIDS, in other words, are vital components of marine research and an important element in modern environmental protection, assisting efforts towards sustainable development.

A further argument supporting the usefulness of information systems to marine research is that users of data (e.g. international agencies, governments, environment NGOs or scientists) have a basic interest in ascertaining the coverage of data and their quality. In some fields, there is a long history for precisely defined data collections based on equally well defined monitoring, e.g. for climate, air conditions, forest and -to a larger extent- also water conditions. The same is true for marine research. It is therefore important that support be provided by information systems, so that such information is really put to use. 
Information systems, however, also need to adapt themselves to fit in more closely with marine research. In adapting themselves to cover more aspects of marine research, information systems such as BEIDS, for example, need to pay more attention to items such as monitoring of species, habitats, main threats, climate change impacts and cultural heritage condition; quality control at all stages and the analysis, interpretation and distribution of data to decision-makers and the public. The best approach for the future seems, therefore, to build on existing systems and complement them so as not only to the ensure (higher) quality of the information, but also obtain higher resolution and penetration in different sectors of society. Finally, links with other relevant international monitoring organisations may also prove useful and may allow information systems to operate within reasonable cost/benefit levels.

\section{REFERENCES}

BALTEX.The Baltic Sea Experiment. Project information. Geesthacht: GKSS Research Centre, 1999.
BALTIC SEA WEB. Project information. Espoo: Technical Research Centre of Finland, 1999.

EUROPEAN DIRECTORY OF MARINE ENVIRONMENTAL DATA. Project information, Merseyside, UK: British Oceanographic Data Centre (BODC), 1999.

GREN, I.M.; SÖDERQVIST, T.; AD WULFF, F. Nutrient reductions to the baltic sea: Ecology, costs and benefits. Journal of Environmental Management, v.51, p.123-143, 1997.

JANSSON, Å.; FOLKE, C.; ROCKSTRÖM, J.; GORDON, L. Linking freshwater flows and ecosystem services appropriated by people: The case of the Baltic Sea Drainage Basin. Ecosystems, v.2, p.351-366, 1999.

JANSSON, B.O. The Baltic Sea: current and future status and impact of agriculture. Ambio, v.26, p.423-431, 1997.

JOENNIEMI, P. Cooperation in the baltic sea region. Washington: Taylor \& Francis, 1993.

KINDLER, J.; LINTNER, S.F. An action plan to clean up the baltic. Environment, v.35, p.7-15, 1993.

LEAL FILHO, W. The baltic environmental information dissemination system. In: CONFERENCE ON ENVIRONMENTAL INFORMATICS. Bonn, 2000. (in press) 